\title{
PERKEMBANGAN SEL LIMFOSIT B DAN PENANDANYA UNTUK FLOWCYTOMETRY
}

\author{
Yelvi Levani
}

Fakultas Kedokteran Universitas Muhammadiyah Surabaya

Korespondensi: blue levani@yahoo.com

\begin{abstract}
ABSTRAK
Sel limfosit B merupakan bagian dari respon imunitas adaptif yang berperan penting untuk pertahanan tubuh melawan patogen. Perkembangan sel limfosit B dimulai dari sel punca hematopoietik di sumsum tulang belakang dan organ limfoid sekunder dengan melalui berbagai tahapan proses maturasi dan seleksi. Sel limfosit B matur dapat menghasilkan berbagai macam antibodi yang spesifik untuk patogen. Di tiap perkembangannya, sel limfosit B memiliki ekspresi molekul yang berbeda pada permukaannya dan dapat diketahui dengan pemeriksaan flowcytometry. Pemeriksaan sel limfosit B yang sesuai dengan tahapan perkembangannya dapat digunakan untuk membantu diagnosis penyakit defisiensi imun kongenital, leukemia, limfoma dan penyakit autoimun.
\end{abstract}

Kata kunci: Limfosit B, perkembangan, penanda, flowcytometry

\section{ABSTRACT}

Lymphocyte B cell is part of adaptive immune system to defense from pathogen. Lymphocyte B cell develop from hematopoietic precursor cells to be mature lymphocyte B cells through differentiation and maturation process in bone marrow and secondary lymphoid organ. Mature lymphocyte B cell produces specific antibody for different pathogens. In each step, lymphocyte B cell has different molecule expression and can be examined by using flowcytometry. Lymphocyte B cell examination in each step can be used to diagnose congenital immunodeficiency, leukemia, lymphoma and autoimmune disease.

Keywords: lymphocyte B, development, marker, flowcytometry 


\section{PENDAHULUAN}

Secara umum sistem imun dibagi menjadi dua lini: imunitas alamiah dan imunitas adaptif. Imunitas alamiah (innate) adalah pertahanan lapis pertama, berupa mekanisme non-spesifik (antigenindependent) untuk melawan dan mengatasi patogen yang menerobos masuk ke dalam tubuh kita. Imunitas adaptif bersifat spesifik terhadap antigen (antigen-dependent), dan memiliki memori sehingga tubuh kita mampu bereaksi dengan lebih cepat serta lebih efisien pada saat terpapar ulang dengan antigen yang sama. Sel limfosit B termasuk dalam imunitas adaptif. Selain memiliki kemampuan mengenali antigen secara spesifik, sel limfosit B juga dapat mengsekresi antibodi atau immunoglobulin. Sel limfosit B dan antibodi merupakan elemen uatma dari respon imun humoral sebagai pertahanan tubuh terhadap berbagai patogen. Gangguan pada perkembangan, seleksi dan fungsi sel limfosit B akan menyebabkan penyakit autoimun, keganasan, imunodefisiensi dan alergi. ${ }^{1}$ Dalam telaah pustaka ini akan dibahas secara singkat mengenai asal dari sel limfosit B, perkembangan sel limfosit B di sumsum tulang belakang (bone marrow), perkembangan sel limfosit B menjadi sel plasma dan sel memori serta marker yang bisa digunakan untuk pemeriksaan sel limfosit B dengan flowcytometry

\section{ASAL DARI LIMFOSIT B}

Berdasarkan asal perkembangannya di sumsum tulang belakang (bone marrow), sel imun dibagi menjadi dua kelompok yaitu lini myeloid dan limfoid. Sel imun alamiah sebagian besar termasuk lini myeloid diantaranya; neutrofil, eosinofil, basofil, sel mast, sel monosit/makrofag, dan sel dendritik. Hanya sel NK (natural killer cell) sel imun alami yang termasuk lini limfoid. Sedangkan semua sel imun adaptif berasal dari lini limfoid diantaranya sel limfosit Th ( $\mathrm{T}$ helper), sel limfosit Tc (T cytotoxic) dan sel limfosit B. ${ }^{2}$

Sel limfosit B (bursal atau bone marrow) merupakan kumpulan populasi sel yang mengekspresikan berbagai reseptor immunoglobulin (Ig) di permukaan sel nya untuk mengenali berbagai macam epitop spesifik dari antigen. Sel limfosit B diproduksi di hati janin (fetal liver) saat di dalam kandungan dan di sumsum tulang belakang. Perkembangan sel limfosit B kemudian berlanjut di organ limfoid sekunder seperti kelenjar getah bening (lymph node), limpa (spleen), jaringan limfoid sekunder pada mukosa (mucosal associated lymphoid tissue / MALT), jaringan limfoid sekunder pada usus (gut associated lymphoid tissue / GALT) dan tonsil untuk menjadi sel plasma ataupun sel limfosit B memori. ${ }^{3}$ Sel limfosit B memiliki lima kelas antibodi yaitu Ig-A, Ig-D, Ig-E, Ig-M dan Ig-G.

\section{PERKEMBANGAN SEL LIMFOSIT B DI SUMSUM TULANG BELAKANG}

$$
\text { Perkembangan sel limfosit B }
$$
membutuhkan beberapa tahapan yang dimulai dari progenitor sel limfoid (common bymphoid progenitor / CLP) untuk menjadi sel limfosit B yang matur di sumsum tulang belakang. CLP sendiri berasal dari hematopoietic stem cells (HSC) yang sudah tidak 
memiliki potensi lini myeloid. CLP dapat berkembang menjadi sel limfosit $\mathrm{T}$, sel limfosit $\mathrm{B}$ dan sel dendritik (DC). Reseptor sel limfosit B memiliki dua jenis rantai yaitu rantai $\mathrm{H}$ (heary chain/rantai berat) dan rantai L (light chain / rantai ringan) yang memiliki berbagai lokus gen. Imunoglobulin yang lengkap (Ig) memiliki 2 rantai $\mathrm{H}$ dan 2 rantai L. Pada tahapan awal perkembangan sel limfosit B membutuhkan rekombinasi dari lokus gen $\mathrm{V}, \mathrm{D}, \mathrm{J}$ di rantai $\mathrm{H}$ $\left(\mathrm{VDJ}_{\mathrm{H}}\right)$ dan lokus gen $\mathrm{V}, \mathrm{J}$ di rantai ringan $\left(\mathrm{VJ}_{\mathrm{L}}\right)$. Rekombinasi segmen gen tersebut membuat kumpulan sel limfosit B memproduksi antibodi yang dapat mengenali lebih dari $5 \times 10^{13}$ jenis antigen berbeda. Terdapat tiga tahapan perkembangan sel limfosit B berdasarkan tahap rekombinasi dan penyusunan gen pembentuk rantai $L$ dan rantai $H$, yaitu sel pro $B$ merekombinasi segmen gen $\mathrm{D}$ dan $\mathrm{J}$ pada rantai $\mathrm{H}$, diikuti dengan rekombinasi kedua pada bagian segmen $\mathrm{V}$ untuk menggabungkan dengan segmen DJ. ${ }^{4}$

Perkembangan sel limfosit B diregulasi oleh SLC (surrogate L chain) yang terdiri dari dua protein yaitu $\lambda 5$ dan VpreB. Kedua protein ini berikatan dengan protein $\mu$ pada rantai $\mathrm{H}$ dan membentuk pre BCR. Prerkursor sel B atau pre sel B dibentuk dari Pro sel limfosit B yang mengekspresikan pre BCR di permukaan selnya. Untuk perkembangan sel limfosit B berikutnya dibutuhkan gen Bruton's tyrosine kinase (Btk) dan sitokin IL-7.5 Mutasi pada gen Btk dapat menyebabkan penyakit X-linked agammaglobulinemia. ${ }^{6}$ Jalur sinyal BCR dalam perkembangan sel limfosit B ini mendapatkan banyak perhatian dari klinisi. Tidak hanya dapat digunakan untuk membedakan agammaglobulinemia dengan jenis hipoglobulinemia yang lain, tetapi inhibisi jalur BCR ini dapat digunakan sebagai terapi baru yang menjanjikan untuk menangani limfoma sel limfosit $\mathrm{B}^{7}$ dan penyakit autoimun. ${ }^{8}$

Bila reseptor pre BCR tidak dapat muncul pada permukaan sel karena kesalahan rekombinasi gen VHDJH pada rantai $\mathrm{H}$ maka perkembangan sel limfosit B akan berhenti dan sel akan melakukan apoptosis. Bila sinyal pre BCR berfungsi baik, maka akan dihasilkan RAG1/2 dan terjadi rekombinasi gen di rantai L. Bila rekombinasi rantai L berhasil, maka akan terbentuk reseptor IgM pada permukaan sel limfosit B yang imatur. Kegagalan saat rekombinasi gen di rantai $\mathrm{L}$ akan menyebabkan terjadinya proses apoptosis. ${ }^{3}$ Sel limfosit B imatur dapat meninggalkan sumsum tulang belakang dan bermigrasi ke limpa, dimana sel limfosit B imatur tersebut berdiferensiasi menjadi sel limfosit B naïve, folikuler atau marginal zone (MZ). ${ }^{1}$

Tantangan pertama sel imun adalah untuk menemukan keseimbangan antara spesifisitas antibodi dalam melawan berbagai patogen tetapi dapat menghindari autoreaktivitas. Reseptor sel B (B cell receptor/BCR) pada sel limfosit B imatur diuji tubuh apakah dapat berikatan dengan antigen tubuh atau tidak. BCR yang dapat berikatan dengan tubuh atau memiliki sifat autoreaktif dapat mengalami apoptosis atau mengalami proses edit ulang pada reseptor rantai L nya oleh RAG1. ${ }^{3}$ Sel 
limfosit B imatur memiliki IgM yang fungsional, tetapi belum memiliki Ig yang lain. Sel limfosit B yang imatur terbagi menjadi dua jenis tipe yang dibedakan dengan ekspresi molekul pada permukaan selnya. Sel tersebut dinamakan sel transisi T1 dan T2. ${ }^{9}$ Sel transisi T1 memiliki ekspresi IgM yang tinggi dan $\operatorname{IgD}$ yang rendah, sedangkan sel transisi T2 mengekspreksikan IgD yang lebih tinggi. Sebagian besar sel transisi T1 berubah menjadi sel transisi T2 kemudian menjadi sel limfosit B yang matur. Tetapi 25\% sel transisi
T2 dapat keluar dari sumsum tulang belakang, beredar di sirkulasi darah dan masuk ke kelenjar getah bening serta limpa. Sel limfosit B yang imatur sudah dapat berinteraksi dengan antigen seperti lipopolisakarida dan menghasilkan antibodi secara cepat tanpa bantuan dari antigen MHC kelas $2 .{ }^{10}$ Sel limfosit B yang matur memiliki IgM dan $\operatorname{IgD}$ di permukaan selnya, kemudian keluar dari sumsum tulang belakang dan menuju organ limfoid sekunder untuk perkembangan lebih jauh.

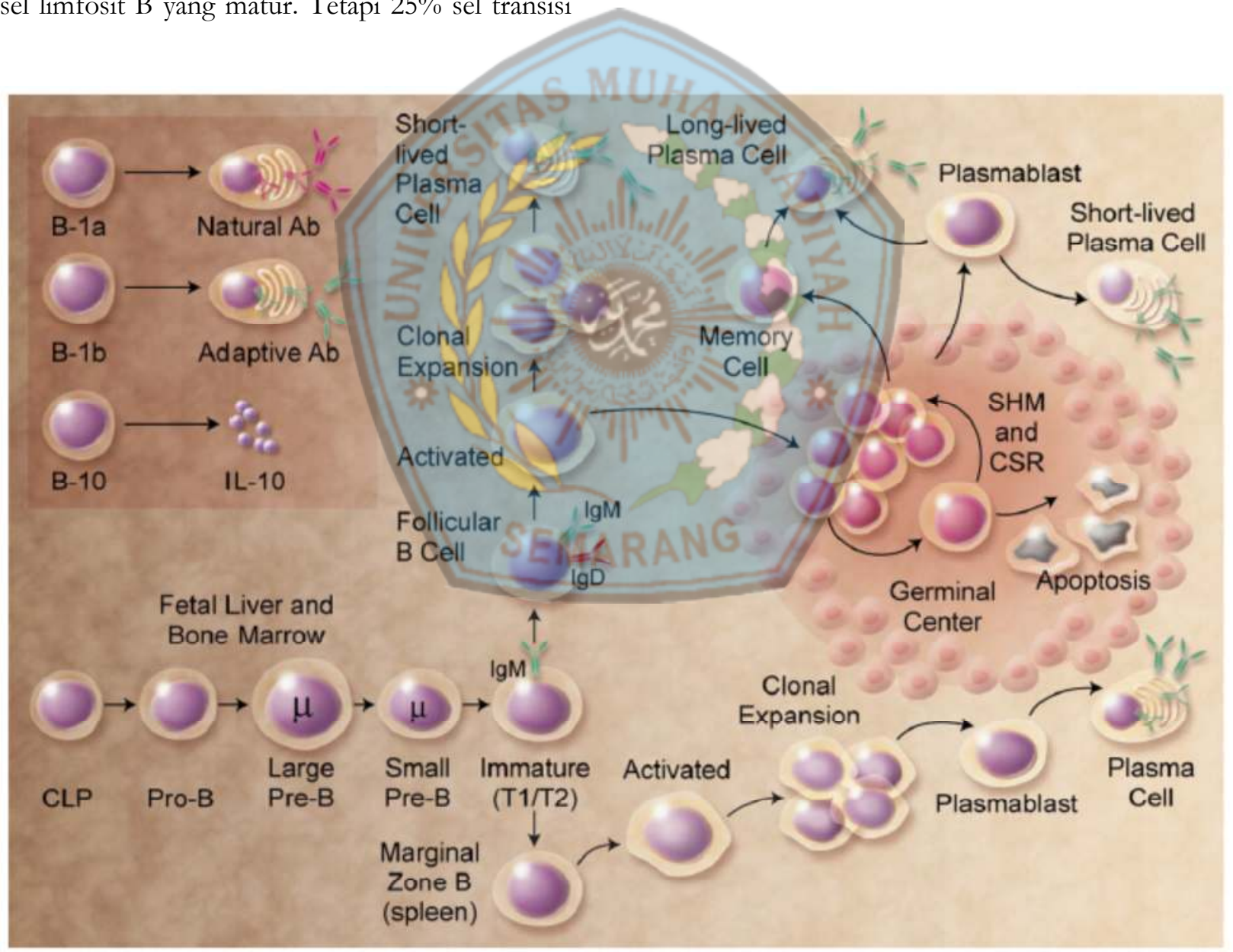

Gambar1. Tahapan perkembangan sel limfosit B ${ }^{3}$

\section{PERKEMBANGAN SEL LIMFOSIT B MENJADI SEL PLASMA DAN SEL LIMFOSIT B MEMORI}

Sebagian besar sel limfosit B yang matur berada di dalam folikel limfoid kelenjar getah 
bening dan limpa. Di dalam folikel tersebut, sel B dapat berinteraksi dengan antigen yang tergantung

pada sel T ( $T$ cell dependent / TD) dan berikatan dengan sel dendritik folikuler untuk berproliferasi, kemudian berdiferensiasi menjadi sel plasma atau menetap di germinal center (GC). Sebagian sel limfosit B yang teraktivasi dan berubah menjadi sel plasma keluar dari folikel dan berpindah ke corda medulla kelenjar getah bening atau sumsum tulang belakang. Sel plasma ini dapat menghasilkan IgM selama 4 hari. ${ }^{11}$

Sel limfosit B yang teraktivasi dan menetap di germinal center mengalami proses somatic bypermutation (SHM) dan seleksi klonal untuk membentuk kompartemen dari imunitas humoral. ${ }^{12}$ Proses SHM ini berperan dalam pembentukan kelas antibodi atau immunoglobulin dan dimediasi oleh enzim activation-induced cytidin deaminase (AID). ${ }^{13}$ Pembentukan kelas ini dinamakan class switching. Selain dipengaruhi oleh antigen yang tergantung pada sel $\mathrm{T}$, class switching juga tergantung pada sitokin diantaranya sitokin IL-4 untuk membentuk IgG1 dan IgE, sitokin TGF-b untuk membentuk IgA dan IgG2b, sitokin IL-5 untuk membentuk IgA dan IFN-y untuk membentuk IgG3 dan IgG2a. Sel limfosit B yang memiliki daya afinitas yang rendah serta autoreaktif akan mengalami proses apoptosis. Sedangkan sel yang memiliki daya afinitas yang tinggi dan tidak autoreaktif akan menjadi sel B memori. Bila terpapar dengan antigen yang sama untuk kedua kalinya maka sel B memori tersebut dapat menghasilkan antibodi yang memiliki daya afinitas yang tinggi. ${ }^{3}$

Sel limfosit B sendiri memiliki beberapa subset atau tipe diantaranya sel limfosit B B1, sel limfosit B B2 (folikuler/konvensional) dan sel limfosit B marginal zone (MZ) yang dibedakan oleh fenotip, lokasi anatomi dan produksi antibodi natural. $^{3}$ Sel limfosit B1-1 ditemukan di peritoneum dan dibedakan lagi menjadi sel limfosit B B1-a dan sel limfosit B B1-b. ${ }^{14}$ Sel limfosit B B1-a memproduksi antibodi alami untuk melawan bakteri sebagai bagian dari kekebalan alami, sedangkan sel limfosit B B1-b dapat berintaraksi dengan polisakarida dan antigen lain yang tidak bergantung dengan sel limfosit $\mathrm{T}$ ( $T$ cell independent). Sel limfosit B MZ berasal dari sel transisi T2 dan berada di luar folikel. Sel limfosit B MZ mengekspresikan IgM yang tinggi dan $\operatorname{IgD}$ yang rendah. ${ }^{15}$

\section{PENANDA YANG BISA DIGUNAKAN UNTUK PEMERIKSAAN SEL LIMFOSIT B DENGAN FLOWCYTOMETRY}

Sel limfosit B memiliki berbagai macam molekul di permukaan selnya. Untuk memudahkan mengenali berbagai molekul permukaan tersebut, WHO membuat sistem Cluster Differentiation yang disingkat dengan CD dengan menggunakan teknik monoclonal anti body (mAb). CD19 merupakan molekul yang diekspresikan oleh permukaan sel limfosit B selama masa perkembangannya. CD20 merupakan molekul yang terdapat pada sel limfosit B matur yang berfungsi sebagai pelekat channel $\mathrm{Ca}^{2+}$ di 
membran sel. Saat ini terdapat obat mAb CD20 yaitu Rituximab yang telah diuji coba dan digunakan secara luas untuk menangani kanker darah. CD21 merupakan reseptor yang dapat berikatan dengan CD19 untuk memberikan sinyal dan menginformasikan ada proses inflamasi pada sel limfosit B. CD22 berfungsi untuk mengatur proses seleksi positif dan negatif pada sel limfosit B folikel. CD23 merupakan reseptor yang berikatan lemah untuk $\mathrm{IgE}$ pada sel limfosit B yang teraktivasi untuk memproduksi IgE. CD24 merupakan molekul yang dapat ditemukan di semua sel limfoist B, sel granulosit dan sel epitel. CD40 berperan sebagai faktor survival yang penting untuk sel B di germinal center (GC) dan untuk berinteraksi dengan sel limfosit $\mathrm{T}$ dengan menggunakan ligand CD154. CD72 berfungsi sebagai negative regulator dari sinyal transduksi dan CD79a.b diekspresikan di permukaan sel limfosit B. ${ }^{3}$

Di tiap tahapan perkembangan sel limfosit B terdapat ekspresi molekul CD yang unik di permukaan selnya. Pre-Pro sel B mengekspresikan CD45R yang merupakan penanda spesifik untuk lini sel B. Pro sel B mengekspresikan CD19 yang terlibat dalam pengenalan antigen dan mengekspresikan CD34. Pre sel B mengekspresikan CD79a dan CD79b yang juga merupakan komponen Ig pada limfosit B matur. Sel limfosit B imatur sudah memiliki antibodi IgM yang fungsional tetapi belum memiliki jenis Ig yang lain. Sel limfosit B imatur mengekspresikan B220, CD25, IL-7R dan CD19. Sel limfosit B memiliki 2 jenis sel transisi yaitu T1 dan T2. Sel transisi T2 memiliki ekspresi IgD yang lebih tinggi, CD21+ dan BAFF-R. Sedangkan sel transisi T1 memiliki ekspresi IgM yang tinggi, IgD yang rendah, CD21-, CD23-, CD24+ dan CD 93+. Sebagian besar sel transisi T1 berubah menjadi sel transisi T2 dan berkembang menjadi sel limfosit B matur. Sel limfosit B yang matur mengekspresikan HLA-DR, CD19, CD20 dan CD40 di permukaan selnya dan memiliki IgM dan IgD. Sel plasma sudah tidak mengekspresikan CD19 dan CD20 lagi, tetapi mengekspresikan XBP-1, BLIMP-1, CD38 dan Ig sitoplasma. Sel limfosit B memiliki beberapa jenis diantaranya Sel B folikuler (B2) yang merupakan sel limfosit B yang konvensional, sel B B-1 dan sel B marginal zone (MZ) yang memiliki perbedaan ekspresi molekul di permukaan selnya. Sel B B-1 mengekspresikan CD43, CD5 dan IgM tinggi. Sedangkan sel B MZ mengekspresikan CD21 dan IgM tinggi. ${ }^{3}$

Untuk pemeriksaan sel limfosit B, baik untuk kepentingan diagnostik ataupun penelitian biasanya digunakan alat flowcytometry. Flowcytometry merupakan suatu alat untuk menganalisis populasi suatu sel dengan menggunakan teknik immunofluoresens yang menggunakan antibodil monoclonal $(\mathrm{mAb})$ sehingga dapat berikatan dengan $\mathrm{CD}$ yang sesuai dengan $\mathrm{mAb}$ tersebut. Flowcytometry dapat mengukur karakteristik fisik tiap sel yang akurat termasuk ukuran dan granularitas sel secara simultan. ${ }^{16}$ Pemeriksaan sel limfosit B yang sesuai dengan tahapan perkembangannya dapat digunakan untuk membantu diagnosis penyakit defisiensi imun 
kongenital, leukemia, limfoma dan penyakit autoimun.

\section{KESIMPULAN}

Sel limfosit B merupakan bagian dari imunitas adaptif yang dapat menghasilkan antibodi. Sel limfosit B dibentuk di sumsum tulang belakang dan mengalami aktivasi dan maturasi di organ limfoid sekunder. Setelah berinteraksi dengan antigen yang tergantung pada sel $\mathrm{T}$ dan berikatan dengan sel dendiritik, sel limfosit B yang matur dapat berubah menjadi sel plasma atau sel limfosit B memori. Di tiap perkembangannya, sel limfosit B memiliki ekspresi molekul yang berbeda pada permukaannya dan dapat diketahui dengan pemeriksaan flowcytometry.

Tabel 1. Daftar molekul CD yang diekspresikan di permukaan sel limfosit B[3]

\begin{tabular}{|c|c|c|c|}
\hline Name & Original names & Cellular reactivity & Structure \\
\hline CD19 & B4 & Pan-B cell, FDCs? & Ig superfamily \\
\hline $\mathrm{CD} 20$ & B1 & Mature B cells & MS4A family \\
\hline CD21 & B2, HB-5 & Mature B cells. FDCs. & Complement receptor family \\
\hline CD22 & BL-CAM, Lyb-8 & Mature B cells & Ig superfamily \\
\hline $\mathrm{CD} 23$ & $F_{C E R}$ & Activated B cells, FDCs, others & C-type lectin \\
\hline $\mathrm{CD} 24$ & $B A-1, H B 6$ & Pan-B cell, granulocytes, epithelial cells & GPI anchored \\
\hline CD40 & Bp50 & B cells, epithelial cells, FDCs, others & TNF receptor \\
\hline CD72 & Lyb-2 & Pan-B cell $1:-1 n=$ & C-type lectin \\
\hline CD79a,b & $\lg \alpha, \beta$ & Surface $\lg ^{+} B$ cells & Ig superfamily \\
\hline
\end{tabular}

\section{DAFTAR PUSTAKA}

1. Pieper K, Grimbacher B, Eibel H. B cell biology and development. J Allergy Clin Immunol 2013;131(4):959-71.

2. Todd I,Spickett G, Fairclough L. The nature of immune system. In: Todd I,Spickett G, Fairclough L. Immunology Lectures Note. $7^{\text {th }}$ edition. West Sussex, Wiley Blackwell. 2015. p: 3-12.

3. LeBien TW, Tedder TF. B lymphocytes: How they develop and function. Blood. 2008;112: 1570-1580

4. van Zelm MC, Szczepanski T, van der Burg $M$, van Dongen JJ. Replication history of B lymphocytes reveals homeostatic proliferation and extensive antigeninduced $\mathrm{B}$ cell expansion. J Exp Med 2007;204:645-55.
5. Matthias P, Rolink AG. Transcriptional networks in developing and mature B cells. Nat Rev Immunol 2005;5:497-508

6. Conley ME, Mathias D, Treadaway J, Minegishi Y, Rohrer J. Mutations in btk in patients with presumed $\mathrm{X}$-linked agammaglobulinemia. Am J Hum Genet 1998; 62:1034-43.

7. Ponader S, Chen SS, Buggy JJ, Balakrishnan $\mathrm{K}$, Gandhi V, Wierda WG, et al. The Bruton tyrosine kinase inhibitor PCI-32765 thwarts chronic lymphocytic leukemia cell survival and tissue homing in vitro and in vivo. Blood 2012;119:1182-9

8. Hutcheson J, Vanarsa K, Bashmakov A, Grewal S, Sajitharan D, Chang BY, et al. Modulating proximal cell signaling by 
targeting Btk ameliorates humoral autoimmunity and end-organ disease in murine lupus. Arthritis Res Ther 2012; 14:R243.

9. Chung JB, Silverman M, Monroe JG. Transitional B cells: step by step towards immune competence. Trends Immunol. 2003;24:343-349

10. Marshall-Clarke S, Tasker L, Parkhouse RME. Immature B lymphocytes from adult bone marrow exhibit a selective defect in induce hyperexpression of major histocompatibility complex class II and fail to show B2.7 induction. Immunol. 2000;100(2):141-151.

11. Balazs M, Martin F, Zhou T, Kearney J. Blood dendritic cells interact with splenic marginal zone $\mathrm{B}$ cells to initiate $\mathrm{T}$ independent immune responses. Immunity 2002;17:341-52.

12. Muramatsu M, Kinoshita K, Fagarasan S,Yamada S, Shinkai Y, Honjo T. Class switch recombination and hypermutation require activation-induced cytidine deaminase (AID), a potential RNA editing enzyme. Cell. 2000;102:553-563

13. Revy P, Muto T, Levy Y, Geissmann F, Plebani A, Sanal O, et al. Activation-induced cytidine deaminase (AID) deficiency causes the autosomal recessive form of the HyperIgM syndrome (HIGM2). Cell 2000;102:56575.

14. Allman D, Pillai S. Peripheral B subset. Curr Opin Immunol. 2008;20(2):149-157.

15. Haas KM, Poe JC, Steeber DA, Tedder TF. B-1a and B-1b cells exhibit distinct developmental requirements and have unique functional roles in innate and adaptive immunity to $S$. pneumoniae. Immunity. 2005;23:7-18.

16. Adan A, Alizada G, Kiraz Y, Baran Y, Nalbant A. Flow cytometry: basic principles and applications. Crit Rev Biotechnol. 2017;37(2):163-176. 